\title{
Challenges and Prospects of Youth Entrepreneurship Development in a Designated Community in the Western Cape, South Africa
}

\author{
${ }^{1}$ Saphetha Appie Gwija*, ${ }^{2}$ Chuks Eresia-Eke, ${ }^{1}$ Chux Gervase Iwu \\ Cape Peninsula University of Technology, South Africa \\ University of Pretoria, South Africa \\ *sgwija@gmail.com
}

\begin{abstract}
In a job-scarce environment, where unemployment is rife the need for fostering entrepreneurship especially among youth is a prime concern. This is arguably the case in South Africa, where despite a number of government-pioneered interventions, the level of youth entrepreneurship, particularly in township areas remains unsatisfactory. This study takes a two-pronged approach to establish specific factors that are inhibiting youth entrepreneurship development, and determine the prospects of youth entrepreneurship development in Khayelitsha in the Western Cape, South Africa. The data was collected via self-administered questionnaires that were distributed to 132 respondents, which were randomly drawn from a population of 200 youth entrepreneurs registered on the database of a local organisation which promotes and develops entrepreneurship in the Western Cape. The findings revealed, among others, that a major inhibiting factor to entrepreneurship development is the lack of awareness and inaccessibility of youth entrepreneurship support structures and initiatives in this community. Interestingly though, this hindrance does not appear to have a negative bearing on the identified growing enthusiasm of the youth to engage in entrepreneurial activities. Overall, on the basis of the challenges and prospects revealed, recommendations to improve the current situation are made. This study is an applied research effort and its relevance is linked to the fact that it provides rare insight into the state of youth entrepreneurship in a large but under-researched township community in the Western Cape. The findings and recommendations therefore bear far-reaching ramifications for all stakeholders who are concerned about developing youth entrepreneurship in this society.
\end{abstract}

Keywords: Youth entrepreneurship, Youth entrepreneurial ventures, Entrepreneurship development, Western Cape, South Africa

\section{Introduction}

Entrepreneurship has been adopted world over, as a strategy to facilitate economic participation among young people (Musengi-Ajulu, 2010:1; Nafukho \& Muyia, 2010:100). The European Commission (2003:22) argued that academics, practitioners and policy makers worldwide have heightened their commitment towards promoting an entrepreneurial mindset in the society. In 1994, Nelson Mandela articulated that youth are a valued possession of the nation. Without them, such initiatives as the reconstruction and development programme (RDP) would be meaningless (Gordon-Davis \& Cumberlege, 2007:8). These words according to Gordon-Davis and Cumberlege (2007:8) capture the need for South African business environment to acknowledge the crucial role which youth entrepreneurs can play in improving not only their wellbeing, but also that of their country's economy. In South Africa youth entrepreneurship received a considerable focus after the establishment of Umsobomvu Youth Fund (UYF) in 2001 (Nieman \& Nieuwenhuizen, 2009:42). The objective of the latter was to stimulate an entrepreneurial mindset among young people, and assist them with business funding and market access (Nieman \& Nieuwenhuizen, 2009:197). In 2009 UYF merged with the National Youth Commission (NYC) to give birth to the National Youth Development Agency (NYDA) (Chabane, 2011). This establishment was formed to respond to a variety of challenges for young people in the country, such as unemployment, drug and alcohol abuse and HIV and Aids (South Africa. NYDA Annual Report, 2010:3).

On the other hand, South Africa's Department of Trade and Industry (DTI) through its endeavours to facilitate the country's economic growth, wealth and job creation, has made various strides such as the establishment of institutional framework for supporting SMMEs (Nieman \& Nieuwenhuizen, 2009:201). In the past few years the latter has developed a draft, the National Youth Economic Empowerment Strategy and Implementation Framework (NYEESIF) for 2009-2019 (South Africa. DTI, 2009:11). Its key objectives are to improve the quantity and quality of youth entrepreneurship and technical knowledge, reduce poverty and unemployment among young people (South Africa. DTI, 2009: 8). Also, there are 
other independent support structures in the country that provide various initiatives to young people. These include South African Breweries (SAB) (Swanepoel, Streydom \& Nienwenhuizen, 2010:58); the Junior Achievement South Africa (JASA, 2009:3); the South African Youth Chamber of Commerce (SAYCC, 2010); and the Branson School of Entrepreneurship (Virgin Unite, 2011).

Despite the existence of the above mentioned support structures and initiatives in the country, the level of youth entrepreneurship development particularly in township areas remains unsatisfactory. Therefore, the current study seeks answers to the following research questions:

- What are the specific factors inhibiting the development of youth entrepreneurship in the Khayelitsha community in the Western Cape?

- What are the prospects of youth entrepreneurship development in the Khayelitsha community in the Western Cape?

The research questions are posed to aid the achievement of the following objectives for this research:

- To find out the specific factors inhibiting the development of youth entrepreneurship in the Khayelitsha community in the Western Cape.

- To determine the prospects of youth entrepreneurship development in the Khayelitsha community in the Western Cape.

The relevance of the current study is linked to the fact that it provides rare insight into the state of youth entrepreneurship in a large but under-researched township community in the Western Cape. Its findings and recommendations therefore bear far-reaching ramifications for all stakeholders (policy makers; researchers; private institutions; donors; entrepreneurship educators; and youth development practitioners) who are concerned about developing youth entrepreneurship in the Khayelitsha area.

\section{Literature Review}

Research indicates that youth group may vary across regions and within countries. For instance, United Nations' definition of youth includes young people that are between the ages 15-24 (UNOWA, 2005:5; International Labour Office, 2006:2). According to the African Union (2006), youth are young people who are between the ages of 15 and 35 years. Conversely, in South Africa a slight broader definition of youth to that of African Union was adopted. In South Africa, a youth group includes young people who fall within the age of 14 and 35 years (South Africa. National Youth Policy, 2009:12). In addition, this definition is based on the mandate of the South Africa's National Youth Commission Act 1996 and the National Youth Policy 2000. To this end, the upper age limit of youth in South Africa remains 35 years, as a result of the current and historical imbalances, which have not yet been fully addressed (South Africa. National youth Policy, 2009:12). For this study, youth are defined as young people who are between the ages of 16 and 35.

Prior to the democratic era in South Africa, young people were a vulnerable group in the society (Youth Development Network, 2004:1). The apartheid era's exclusion of black South Africans from freely partaking in the country's economy left behind unbearable discrepancies and adversities, particularly within the socio-economic landscape (Human, 2006:2). After 1994 South Africa developed new polices and put in place some transformation measures so as to improve the unpleasant conditions left behind by the apartheid government (Mkoka, 2012:11). A number of programmes were created, such as Youth Development Forum (YDF), Expanded Public Works Programme (EPWP), Accelerated and Shared Growth Initiative for South Africa (ASGISA), Joint Initiative on Priority Skills Acquisition (JIPSA), in an attempt to address youth challenges (South Africa. National Youth Policy, 2009:14). Nevertheless, poverty alleviation, unemployment reduction, and creation of a favourable business environment for youth to participate fully and meaningfully in the country's economy remain the challenge in the country (South Africa. DTI, 2009:6; South Africa. NYDA, 2011:9). Musengi-Ajulu (2010:1) also agrees that even though these initiatives have resulted in the creation of more economic opportunities for young people, it appears that they have no significant impact on reducing the high unemployment rate (estimated at 70 percent) among young people in the country (Fatoki \& Chandoga, 2011:162; Mkoka, 2012:10). James (2012) argues that during this era of high unemployment in the country, fostering youth entrepreneurship could provide a vital antidote. Indeed, numerous countries in Africa have also acknowledged entrepreneurship as an important mechanism for addressing the unemployment agenda, particularly among youth (Nafukho \& Muyia, 2010:100). Nafukho and Muyia also add that investing in entrepreneurship education and training is of critical importance, as it may capacitate and advance human resources, and consequently help with socio-economic development. 
In the context of this research, a youth entrepreneur is described as any young person between the ages of 16-35, who has the ability to recognize an opportunity when it shows, and uses it to create value and wealth by starting a new or growing an existing business venture, in any sector. Since the early 1990s, youth entrepreneurship has received great consideration in South Africa, and has even gained more focus after the establishment of UYF in 2001 (Nieman \& Nieuwenhuizen, 2009:42). UYF merged with the NYC in 2009 to give birth to the NYDA. Chabane (2011) suggests that as a custodian of youth development, the NYDA has a responsibility to facilitate youth entrepreneurship among other things in the country. In addition, the South African government through NYDA, government departments, and some of its partners should continually prioritize youth development in the country (Chabane, 2011). To this end, the NYDA has developed an Integrated Youth Development Strategy (IYDS) and Plan for South Africa (South Africa. NYDA, 2011:9). This IYDS and Plan for South Africa are South Africa's integrated strategy to improve youth development in the country (South Africa. NYDA, 2011:9). Similarly, the DTI through its endeavours to facilitate the country's economic growth, wealth and job creation has made various strides of development, such as the establishment of institutional framework for supporting SMMEs (Nieman \& Nieuwenhuizen, 2009:201). In an effort to acknowledge the importance of youth, in the past few years the DTI has developed a draft of the National Youth Economic Empowerment Strategy and Implementation Framework (NYEESIF) for 2009-2019 (South Africa. DTI, 2009:11). The main objectives of NYEESIF are to improve quantity and quality of youth entrepreneurship and technical knowledge, as well as to reduce poverty and unemployment among the youth (South Africa. DTI, 2009: 8).

Musengi-Agulu (2010:1) asserts that the development of youth entrepreneurship has drastically heightened worldwide. This could be because of the high unemployment facing the youth all over the world, which also appears to be a threat that might persist for decades if there are no effective measures that are established to address it (Schoof, 2006: 1). For instance, the World Bank predicts that by 2015 there will be 25 billion young people under the age of 25 , worldwide; despite the prospects that this generation could be the most educated ever; the ILO's statistics foresee a massive decline in job opportunities (Youth Business International, 2009:3). In South Africa, young people represent majority of the population in numbers (Mahadea, Ramroop \& Zewohir, 2011: 76), however the unemployment among them continues to rise (Fatoki \& Chandoga, 2011:162; Mkoka, 2012:10). This could imply that the majority of young people in South Africa, including those who reside in Khayelitsha, are living under poverty conditions. These conditions could negatively affect them and their families' standard of living (Fatoki \& Chindoga, 2011:162). As a result, criminal activities may occur (Mahadea et al., 2011:67; Mkoka, 2012:10), low self-esteem may persist, which could result in a negative perception of life (Fatoki \& Chindoga, 2011:162). Unfortunately for the less advantaged individuals if these circumstances continue to persist, the next generation may have no choice but to bear the poverty legacy. Morrow et al. (2005:10) caution that poverty normally reproduces itself among children and young people who come from already disadvantaged homes. James (2012) maintains that during this era of high unemployment in the country, more attention should be paid to fostering youth entrepreneurship.

Entrepreneurship aids economic growth, economic competitiveness, economic independence, selfesteem, job creation, social welfare of any country, as well as political stability and national security of a country (European Commission, 2003:22; Linan et al., 2005:1; Dempsey, 2009:2; Fatoki \& Chindoga, 2011:162). Therefore, entrepreneurship would be particularly useful among youth themselves; their families, the society at large, and the country's economy (Fatoki \& Chindoga, 2011:162). Nevertheless, South African youth lag behind in setting up own business ventures compared to their counterparts from other countries (Von Broembsen, Wood \& Herrington, 2005 in Fatoki \& Chindoga, 2011:162). The continuity of this situation may not augur well for youth economic participation, particularly now that the youth are suffering from unemployment in South Africa (Fatoki \& Chindoga, 2011:162). Sandrock (2011) suggests that graduates from universities, as well as matriculants, should be equipped with entrepreneurial skills in order to create more jobs, rather than to seek paid employment. She stresses that a generation of employers, would be much helpful than that of employees. Similarly, Mahadea et al. (2011: 67-68) believe that exploring young people's talent by fostering a culture of entrepreneurship amongst school leavers would be beneficial in their well-being. These writers further point out that, schooling system should be able to develop entrepreneurial attitudes, knowledge and skills in a student. Ndedi (2009:467) acknowledges that entrepreneurship education is being provided in several institutions of higher learning in South Africa. Nonetheless, he suggests that another aspect required from universities in order to be able to effectively deal with the issue of unemployment is the development of business incubators within the universities. He argues that, incubators could assist students in linking theoretical training with practical exposure. He also adds that such incubators should 
be able to provide management guidance and technical assistance to young people and potential youth entrepreneurs in any business related issue.

Mahadea et al. (2011:67-68) argue that on the basis of the dynamic labour market in South Africa, many young people will not find jobs after completing their secondary education. Thus, they caution that youth should consider self-employment as an option, instead of hunting for a wage employment. These writers also suggest that schooling systems should be able to prepare learners with entrepreneurial knowledge, skills, and also influence their attitude towards entrepreneurship. Von Broembsen et al. (2005), GEM (2008) and Herrington, Kew and Kew (2010) in Mahadea et al. (2011:69) concur that as much as there are many elements that can encourage an individual to start a business, such as exposure to entrepreneurship from immediate families, role models, and so on, education system remains the most important factor in this regard (Isaacs, Visser, Friedrich \& Brijal, 2007:613). Interestingly, even though entrepreneurship in South Africa faces a number of adversities (Herrington et al., 2010:31-35), young people are enthusiastic about participating in entrepreneurial activities (Maas \& Herrington, 2008:4). Mpafa (2008:11) argues that there is a growing number of youth entrepreneurs that are starting up in response to business opportunities in the market, rather than starting up owing to necessity circumstances. Herrington, Kew and Kew (2009:111) argue that this growing trend of opportunity-based entrepreneurs has a positive impact on the financial resources of the owners and unemployment reduction in the country.

\section{Methodology}

This study made use of a descriptive research design. A quantitative empirical research approach was employed with the help of self-administered questionnaires. 132 subjects were randomly drawn from the population of 200 youth entrepreneurs that were registered on the database of a local organisation which promotes and develops entrepreneurship among young people in Khayelitsha. The survivalist entrepreneurs were not part of this research, as they normally operate unregistered businesses, which are not registered with the local organisation. The selection of the population for this study was driven by the researchers' belief that, the subjects would bring about worthwhile information to the subject matter under investigation, for the following reasons. The subjects of the study come from a variety of sections that make up Khayelitsha Township; and were registered with the local organisation, which has a reputation for promoting and developing youth entrepreneurship in Khayelitsha.

The research instrument: Questionnaires were personally distributed by one of the researchers to the participants at their places of business. A standardised and identical questionnaire for every respondent was used. This instrument was chosen because of its ability to gather objective and unbiased information (Cupido, 2003:58). Additionally, the fact that the respondents did not have to disclose their names in this investigation reduced chances of false information being supplied. Out of the distributed questionnaires, only 77 of the returned were usable. This represents a response rate of 58.3 percent for the current study.

Reliability of the research instrument: A test re-test reliability assessment of the data collection instrument was conducted. A set of questionnaires was first distributed to ten subjects of the study. Following this was another set of questionnaires identical to the previous ones, distributed to the same subjects, a couple of weeks later. The responses obtained on those two occasions were assessed for consistency, and seven of them correlated. Slight modifications on the instrument were made, to increase chances of its reliability.

\section{Presentation of the findings}

This section presents the results of the study. Tables and a bar chart are used. Discussions related to the key findings in the study follow.

The results for age groups of the participants indicate that the majority of the participants (46.8 percent) comprised those who were between the ages 26-30 years, followed by 40.3 percent of those who were between ages 31-35. Only 13 percent of the participants were between the ages 21-25 years. A large percentage (72.7) of the respondents was males while females represented only 27.3 percent. The results on the highest level of education for the participants indicate that most of them (80.5 percent) had tertiary qualifications, followed by 16.9 percent of those who matriculated. A small percentage $(2.6$ 
percent) of the respondents was of those who only managed to study up to high school level. See Table 1 above.

Table 1: Descriptive statistics of participants

\begin{tabular}{llll}
\hline Item & Group & Frequency & Valid Percent \\
\hline \multirow{2}{*}{$\boldsymbol{g} \boldsymbol{e}$} & $21-25$ & 10 & 13 \\
& $26-30$ & 36 & 46.8 \\
& $31-35$ & 31 & 40.3 \\
Gender & Male & 56 & 72.7 \\
& Female & 21 & 27.3 \\
Education & Tertiary & 62 & 78.5 \\
& Matriculated & 13 & 16.5 \\
& High School (attempted) & 2 & 2.5 \\
\hline
\end{tabular}

Influence of family business: Majority of the respondents in this study (85.7 percent) believe that early involvement in a family business would provide a good entrepreneurial foundation for those who wish to set up a business, while the remainder (14.3 percent) strongly agreed with the statement. See Figure 1 below.

\section{Figure 1: Previous involvement in a family business as a good entrepreneurial foundation}

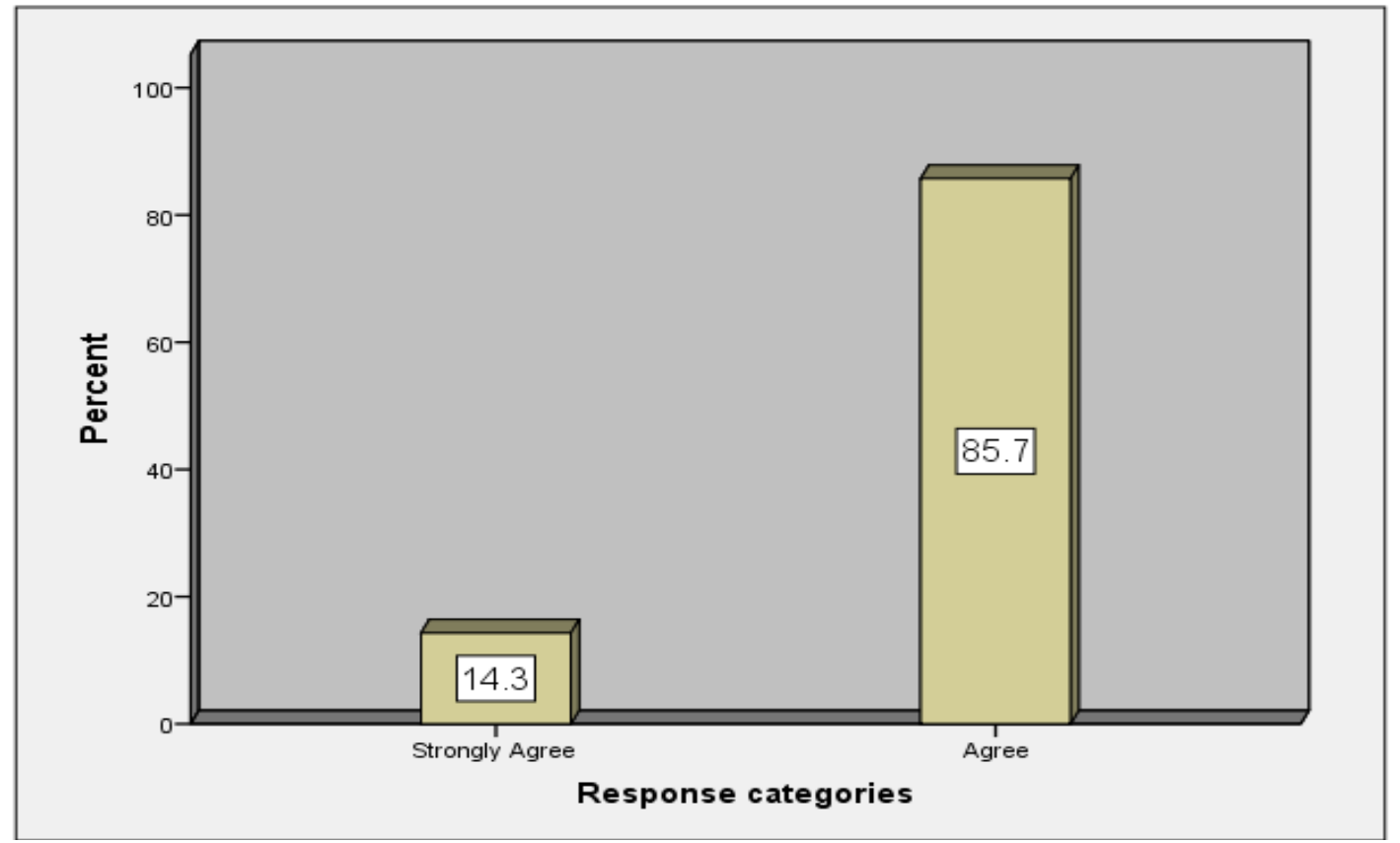

Influence and role of entrepreneurship education and training: 46.8 percent of the participants did not see the value of entrepreneurship education and training in setting up their businesses. 53.2 percent however thought otherwise. The results also indicated that majority of participants (72.7 percent) felt strongly that entrepreneurship education and training could play a big role in the success of any business. This finding aligns with another finding in this study which indicated that entrepreneurial and managerial skills would boost chances of success in their businesses. Beyond these though is an interesting revelation: 63 percent of the participants thought that entrepreneurship was the best option for economic participation rather than paid employment.

Support for youth entrepreneurship in Khayelitsha: It was evident in the study that participants (81 percent) were unaware of any entrepreneurship support structures in Khayelitsha. This may not surprise because 61 percent of them were of the opinion that support structures for youth entrepreneurship (such as the NYDA) had not been helpful. 
Obstacles to setting up a business; While a majority (71 percent) of the participants indicated that access to funding was non-existent, a large proportion (50.6 percent) said that registering a business was an even bigger challenge, in spite of its expensive processes (70.1 percent). See Table 2 below for a list of obstacles identified by the participants in a rank order.

\section{Table 2: Obstacles to setting up a business}

\begin{tabular}{ll}
\hline Rank & Obstacles \\
\hline 1 & Lack of start-up and expansion capital \\
2 & High cost of business resources/Insufficient business resources \\
3 & Poor access to markets \\
4 & Lack of government support \\
5 & Strict business regulations/labour laws/ regulatory red tape \\
6 & Lack of access to business information \\
7 & Poor management practice \\
8 & Difficulties in sourcing the right employees \\
\hline
\end{tabular}

Table 3: Entrepreneurship enthusiasm among young people in Khayelitsha

\begin{tabular}{llllll}
\hline \multicolumn{2}{l}{ Response categories } & Frequency & Percent & Valid Percent & Cumulative Percent \\
\hline Valid & Yes & 77 & 97.5 & 100.0 & 100.0 \\
Missing & System & 2 & 2.5 & & \\
\hline Total & 79 & 100.0 & & \\
\hline
\end{tabular}

Interestingly, all the participants (77 of 77) felt that young people in Khayelitsha were becoming more and more enthusiastic about entrepreneurship. See table 3 above.

Discussion: The study investigated specific factors that were inhibiting youth entrepreneurship development, and determined the specific prospects of youth entrepreneurship development in the Khayelitsha community in the Western Cape, South Africa. This study found that youth-owned businesses in this community experience some hardships in obtaining start-up capital; as a result they end up using their own little funds to set up their business venture. For those aspirant entrepreneurs who cannot afford to raise such funds, some as a result of a lack of savings and collaterals particularly the graduates including those who have acquired entrepreneurship education from tertiary schooling environment may opt for a paid job. At the same time good business opportunities which would be utilised by those who cannot afford, may be in vain. Another inhibiting factor is that of inaccessibility to start-up capital, from government support structures that support youth entrepreneurship in the country. This is in line with Pretorius and Shaw (2004:226), Atieno (2009:1), Herrington et al. (2009:47) and Young Upstarts' (2011:30) findings that that access to start-up capital is a major stumbling block to venturing in a new business. At the same time the inability to access business finance appears to be a persistent trend even at other stages of the business (like growth and maturity stages) as access to expansion capital was also found as a major concern for youth entrepreneurs. Expansion capital is crucial to business as it could be used to acquire business resources such as equipment, raw materials, and human resources to boost business growth and sustainability. Nonetheless, GEM (2011:44) and Young Upstarts (2011:55) also argue that access to business funding remains a hindering factor to entrepreneurship development.

Another issue found was that of the rigid red-tape to such aspects such as simplicity of the business registration process, costs, business regulations and laws. The study revealed that the registration process of a business was not easy to understand. Perhaps a lack of access to business related information prior to the registration of their businesses was the factor. On the other hand, the business registration process was perceived as expensive. Factors such as a lack of start-up capital, as well as possible additional costs charged by the agents assisting with business registration of aspirant entrepreneurs might have influenced the views around this factor. Harrington et al. (2010:32) suggest that the unproductive government bureaucracy, red tape related to setting up and managing a business, as well as restrictive labour regulations need to be revised. The importance of managerial skills in the success of a business venture was emphasised, by the respondents. Van Rensburg (2010) argues that to achieve tremendous entrepreneurial performance, entrepreneurs need to focus on developing their 
business management and entrepreneurial skills, of which in the case of youth entrepreneurs from the designated community, was lacking for some. This factor could also be attributed to their lack of basic business experience. Nieuwenhuizen, De Beer, Zeelle, Groenewald, Watson, Rossouw and Jacobs (2008:2) assert that the development of managerial skills, business knowledge, and nurturing of entrepreneurial skills may help entrepreneurs achieve optimal results. Furthermore, Burke (2006:19) suggests that entrepreneurs need to have a number of management techniques in their portfolio of management skills, in order to effectively manage their new business ventures. These, he said, include project management, small business management, team building and leadership, and risk management skills.

This study also found that it was not an easy task for youth entrepreneurs to find good employees. This position relates to Ohlhoff's (2008:28) argument that attracting a talented workforce is one of the key obstacles facing a number of organisations in the globe. Perhaps this could be linked to high costs associated with employing highly skilled individuals, particularly in a period when the business might still be hunting for financial resources to enable it stabilise. Business support from South African government towards youth entrepreneurship was found to be somewhat unsatisfactory. Some youth entrepreneurs identified such services as business advice, mentorship and financial assistance for youth entrepreneurs as crucial for the success of their businesses; however they were lacking in this community. Similarly, youth support structures (like the NYDA and the DTI) were not perceived as playing much role in developing youth entrepreneurship in Khayelitsha. While Chabane (2011) claims that the NYDA, has the responsibility of facilitating youth entrepreneurship among other things, in Khayelitsha this responsibility was not being discharged. Perhaps this should be attributed to the unavailability of NYDA Youth Advisory Centres (YACs) in Khayelitsha. To foster youth entrepreneurial development, organisations such as the NYDA and DTI's NYEESIF which aim to improve youth entrepreneurship should have more presence in a community like this, where many South African young people are found (South Africa. DTI, 2009: 8). This unavailability of YACs could be one of the reasons why there is a lack of information about existing support structures for youth entrepreneurship development.

The study also found that entrepreneurship education and training was being acknowledged for its catalytic role in the success of the business venture. This is evidenced by the fact that more than half of the participants indicated that it enabled the setting-up of their businesses. According to Van Ransburg (2010) South Africa offers quality education within the field of entrepreneurship, as early as primary school. Mahadea et al. (2011: 67-68) are of the opinion that a culture of entrepreneurship among youth needs to be explored, so as to help them partake in the emergence of entrepreneurship, and ultimately play an extensive role in their well-being as well. These results bear ample testimony to the findings that entrepreneurship was considered the best option for economic participation. These findings are in accord with Mahadea et al. (2011:72) findings, who reported that 78.5 percent of learners in schools were interested in starting their own businesses in the future. Musegu-Ajulu (2010:5) also found that 50 percent of the respondents illustrated that they were interested in becoming entrepreneurs. These results are important for this study as they relate to Sandrock's (2011) ideal that a generation of employers would be much helpful that that of employees in the society.

Respondents felt that the demand for their products and services in the market was likely to continue in the future. Perhaps this was an indication of the level of optimism, which is one of the defining features of an entrepreneur. Interestingly, it was found that it was easy for youth entrepreneurial ventures, to retain good employees. Nonetheless, this finding appears to contradict the position advanced by Ohlhoff (2008:28) that retaining talents was one of globalised business environment challenges. Clearly in Khayelitsha, this situation does not appear to be the case. The reason behind this could be that youth entrepreneurial ventures in this community were reluctant in sourcing highly skilled and experienced individuals, who would demand high salaries and good working conditions in their working environment. Another positive finding was the use of modern technologies in the daily operations of youth entrepreneurs in this community. Perhaps this was because they knew and understood the importance of using superior business resources and capabilities, like modern technologies, in helping to gain and sustain a competitive advantage in the market. This study has also found that numbers of youth entrepreneurs in Khayelitsha were growing. Nevertheless, what was not easy to determine was the extent of such growth in the population of these youth entrepreneurs. Perhaps this was because of the fact that not all youth entrepreneurs in the designated community were registered on the database of the local organisation for youth entrepreneurs mentioned earlier. Over all, this current growth could be seen as a good gesture for youth entrepreneurship in the community. Whilst this is an indication of a growing 
interest of youth in entrepreneurship, the issue of sustenance of their interest seems to be what should be capturing the attention of all stakeholders.

\section{Conclusion and Recommendations}

The study draws the following conclusions:

- Access to start-capital is the primary obstacle at the setting-up of a new business venture, particularly for young people who come from less advantaged backgrounds. Similarly, access to expansion capital is also one of major concerns of youth entrepreneurial venture, as it is crucial in acquiring business resources that could aid growth opportunities of a business venture.

- The business registration process was also perceived as expensive by many. The fact that there are some agents assisting aspirant entrepreneurs with the registration process, claiming to speed-up the process in return for an extra cost may influence this position.

- Sourcing of good employees is among hindering factors to youth entrepreneurial development. This could be linked to high costs associated with employing highly skilled individuals, particularly when the business is still hunting for financial resources to enable it stabilise.

- Lack of business management experience is another stumbling block which youth entrepreneurs are bound to face, as they are still new in the business world, particularly if they have no previous experience in the business industry of their choice.

- Youth support structures (like NYDA and DTI) that should advance youth entrepreneurship in Khayelitsha community are unavailable.

- Youth entrepreneurs in the community have explicit knowledge about the importance of entrepreneurial skills in the success of a business venture.

- There is optimism that the demand for products and services of youth entrepreneurs in the market will persist to continue in future.

- It was established that there is a continued growth in the population of youth entrepreneurs in Khayelitsha. This is supported by the findings which hint that the youth are becoming more and more enthusiastic about entrepreneurship in this community.

On the basis of the above conclusions, the following recommendations are made:

- The South African government should prioritise investment in youth entrepreneurship development initiatives, particularly in less advantaged communities such as Khayelitsha. Support structures (like NYDA and DTI) aimed at nurturing youth entrepreneurship in the country should be visible in this community and be able to assist youth entrepreneurs with finance and non-financial services, at all stages of the business.

- The South African government should take actions to reduce costs associated with business registration for youth, as most of them tend to lack requisite finance, particularly those who are fresh from school and those from less advantaged backgrounds. This could encourage more and young aspirant entrepreneurs to come on board and execute their entrepreneurial aspirations and contribute meaningfully in the economy of this country.

- Regarding business regulations governing youth entrepreneurial ventures, those that are less than one year old should receive tax amnesty, and start paying tax perhaps after two years of their existence.

- Youth entrepreneurship support structures need to create an awareness campaign about their existence. This could be achieved with the help of relevant communication channels such as local radio stations and community newspapers.

- Accessing private institutions such as banks and other microfinance institutions should be made easier by the financial institutions. It is also suggested that youth entrepreneurship funding initiatives be introduced by these financial institutions. Access to the funding initiatives should not be tortuous.

- Youth entrepreneurs themselves should focus on mastering their entrepreneurial and managerial skills, and be hands-on in the daily operation of their businesses, before deciding on sourcing new talents for their businesses. This could also help to improve their business experience. At the same time, it could buy them some time to teach the business know-how to the teams they have in their businesses. In return, this could reduce costs of employing new highly skilled individuals in the business whilst it is still in the nascent phase. 
- Schooling environment should serve as a primary contributor in equipping learners with entrepreneurial and managerial skills, and also influencing their attitudes towards pursuing careers in entrepreneurship, if Sandrock's (2011) ideal of creating a generation of employers is to be realised in the future. At the same time, private organisations should also open doors for learners who need exposure and experience in their businesses. This could possibly be through in-service training, internships, and learnership offerings, even voluntarily service opportunities.

- Interacting with more experienced entrepreneurs within the same industry and other youth entrepreneurship support structures for business know-how, as well as making use of secondary sources like books and the internet should be helpful to those youth entrepreneurs who lack business management experience.

- Strategies to maintain enthusiasm of youth in entrepreneurial activities need to emerge and be correctly implemented. This could be achieved through the creation of favourable business environment, where the business support services are accessible to young people. Government's youth entrepreneurship support structures should partner with local youth entrepreneurship organisations (like the one in Khayelitsha) in staging workshops, conferences and symposia aimed at nurturing young entrepreneurs.

Limitations of the current study: One of the inadequacies of this study is that it was only conducted among youth entrepreneurs registered on the database of a local organisation which promotes and develops entrepreneurship in the Western Cape, South Africa. Therefore, it might not be a good idea to make generalisations of the findings. The context in other geographical areas of South Africa or elsewhere in the world may vary. Again, this study concentrated on profit-making youth entrepreneurial ventures that deal with products and services. Youth entrepreneurs such as corporate, social and adventure entrepreneurs were not part of this study. Nevertheless this study acknowledges the role these entrepreneurs play in their respective communities and in the country's economy.

\section{References}

African Union (2006). The African Youth Charter. Addis Ababa: African Union.

Atieno, R. (2009). Linkages, Access to Finance and the Performance of Small-Scale

Enterprises in Kenya [online]. Available at: http://www.wider.unu.edu/publications/workingpapers/research-papers/2009/en_GB/rp2009-06/. [Accessed April 2012].

Burke, R. (2006). Small Business Entrepreneur: Guide to Running a Small Business. Cape Town: Burke Publishing.

Chabane, C. (2011). Statement by minister in the Presidency, 2011 programme launch [online]. Available at:http://www.info.gov.za/speech/DynamicAction?pageid=461\&sid=18693\&tid=34032. [Accesse d 28 March 2012].

Cupido, C. (2003). Barriers to entrepreneurship in the Western Cape. Unpublished MTech thesis. Cape Town: Cape Technikon.

Dempsey, I. (2009). The Entrepreneurial Dialogues. State of Entrepreneurship in South Africa [online]. Available

at: http://www.gibs.co.za/SiteResources/documents/The\%20Entrepreneurial\%20Dialogu es\%20\%20State\%20of\%20Entrepreneurship\%20in\%20South\%20Africa.pdf. [Accessed 10 October 2010].

European Commission. (2003). The Commission's Green Paper: Entrepreneurship in Europe. London: Stationery Office Limited.

Fatoki, O. \& Chindoga, L. (2011). An Investigation into the Obstacles to Youth Entrepreneurship in South Africa. International Business Research, 4(2), 161-169.

Global Entrepreneurship Monitor. (2008). Global Entrepreneurship Monitor, 2008 Executive Report [online]. Available at: http://entreprenorskapsforum.se/wp-content/uploads/2010/02/GEMGlobal-Report_2008.pdf. [08 July 2013].

Gordon-Davis, L. \& Cumberlege, P. ( 2007). Legal Issues for Entrepreneurs. Cape Town: Juta.

Herrington, M., Kew, J. \& Kew, P. (2010). Global Entrepreneurship Monitor [online]. Available at:http://www.gsb.uct.ac.za/files/GEM2010Report.pdf. [Accessed 28 March 2012].

Herrington, M., Kew, J. \& Kew, P. (2009). Tracking Entrepreneurship in South Africa: A GEM Perspective [online]. Available at: http://www.gsb.uct.ac.za/files/Gembook2009.pdf. [Accessed 10 June 2011]. 
Human, D. (2006). Implementation of Affirmative Action and Black Economic Empowerment (BEE) in the Construction Industry. A paper for quantity surveying industry [online]. Available at: http://www.icoste.org/ASAQS_Human.pdf. [Accessed 28 March 2012].

International Labour Office. (2006). Global Employment Trends for youth. Geneva: ILO Publications.

Isaacs, E. Visser, K. Friedrich, C. \& Brijal, P. (2007). 'Entrepreneurship education and training at the Further Education and Training (FET) level in South Africa'. South African Journal of Education, 27(4), 613-629.

James, W. (2012). Youth entrepreneurship is the key to future growth [online]. Available at: http://www.da.org.za/newsroom.htm?action=view-news-item\&id=10383. [Accessed 28 March 2012].

Junior Achievement South Africa. (2009). Enterprise Education [online]. Available at: http://www.jasa.org.za/site/index.php?option=com_remository\&Itemid=21\&func=startdown\&i $\mathrm{d}=60$. [Accessed 7 July 2011].

Linan, F., Rodriguez-Cohard, J. C. \& Rueda-Cantuche, J. M. (2005). Factors affecting entrepreneurial intention levels, paper presented at the $45^{\text {th }}$ Congress of the European regional Science Association, Amsterdam, 23-27.

Maas, G. \& Herrington, M. (2008). Global Entrepreneurship Monitor South African Report 2007. Cape Town: University of Cape Town Graduate School of Business.

Mahadea, D., Ramroop, S. \& Zewohir, T. (2011). Assessing Entrepreneurship Perceptions of High School Learners in Pietermaritzburg. KwaZulu Natal, 14(1), 66-79.

Mkoka, S. (2012). Towards integrated youth development. My Youth My Future Journal, 1(1), 2-103.

Morrow, S., Pandey, S. \& Ritcher, L. (2005). Where are we now and where are we going: Young people in South Africa, Johannesburg: Umsobomvu Youth Fund.

Mpafa, D. (2008). Youth positive about being entrepreneurs [online]. Available at:http://www.gem.consortium.org/document.aspx?id=778. [Accessed 15 February 2012].

Musengi-Ajulu, S. (2010). What do we know about the entrepreneurial intentions of the youth? In South Africa? Preliminary results of a pilot study [online]. Available at: http://www.uj.ac.za/EN/Faculties/management/departments/CSBD/Documents/MusengiAjulu. pdf. [Accessed 07 December 2011].

Nafukho, F. M. \& Muyia, M. A. H. (2010). Entrepreneurship \& Socioeconomic development in Africa: A reality or myth? Journal of European Industrial Training, 34(2), 96-109.

Ndedi, A. A. (2009). Entrepreneurship Training and Job creation in South Africa: Are Tertiary Institutions Filling the Gap? Journal of Contemporary Management, 6, $463-470$.

Nieuwenhuizen, C., De Beer, A. A., Zeelle, Z., Groenewald, D., Watson, H., Rossouw, D. \& ～Jacobs, H. (2008). Entrepreneurial Skills. Cape Town: Creda communications.

Nieman, G. \& Nieuwenheuizen, C. (2009). Entrepreneurship. A South African Perspective. Cape Town: Interpak Books.

Ohlhoff, S. (2008). The relationship between employees-of-choice status and employer branding. Journal of business and management dynamics, 2, 28 - 35.

Pretorius, R. \& Shaw, G. (2004). Business plan in bank-decision making when financing new businesses. SAJEMS, 7(2), 221-241.

Sandrock, J. (2011). National Report into the state of entrepreneurship. Economic Growth = Growing Entrepreneurship [online]. Available at: http://www.ideate.co.za/2011/0/3/22/economicgrowth-growing-entrepreneurship/. [Accessed 07 April 2011].

Schoof, U. (2006). Stimulating Young entrepreneurship: Barriers and Incentives to enterprise start-up by young people [online]. Available at: http://www.ilo.org/youthmakingithappen/PDF/WP762006-Rev.pdf. [Accessed 02 December 2011].

South Africa. National Youth Development Agency Report. (2011). National Youth Development Agency, Annual Report [online]. Available at: http://www.nyda.gov.za/aboutus/NYDA\%20Strategy/Annual\%20Reports/Pages/default.aspx. [Accessed 20 July 2012].

South Africa. National Youth Policy. (2009). National Youth Policy (NYP) 2009-214 [online]. Available at: http://www.info.gov.za/view/DownloadFileAction?id=102384. [Accessed 11 April 2012].

South Africa. National Youth Development Agency. (2011). The Integrated Youth Development Strategy (IYDS) of South Africa 2012-2016. Johannesburg: National Youth Development Agency.

South African Youth Chamber of Commerce. (2010). Schweitzer Reinecke [online]. Available at:http:www.entrepreneurship.co.za/south_african_youth_chamber_of_commerce_saycc.

[Accessed 07 April 2011]. 
South Africa. The Department of Trade and Industry. (2009). The National Youth Economic Empowerment Strategy and Implementation Framework 2009-2019 (First Draft) [online]. Available http://www.nwpyc.org.za/index2.php?option=com_docman\&task=doc_view\&gid=29\&Itemid=2 . [Accessed 11 April 2012].

Swanepoel, E., Streydom, J. W. \& Nienwenhuizen, C. (2010). An empirical analysis of private company's corporate social investment in SMME development in South Africa. South African Business Review, $14(1), 58-78$.

UNOWA. (2005). Youth Unemployment and regional insecurity in West Africa. West Africa: United Nations.

Van Rensburg, L. J. (2010). National Report into the state of entrepreneurship. Can entrepreneurship be taught/learned? [Online]. Available at: http://www.ideate.co.za/2010/10/20/canentrepreneurship-be-taught/learned/. [Accessed 07 April 2011].

Virgin Unite. (2011). Branson School of Entrepreneurship [online]. Available at: http://www.virgin.com/people-and- planet/blog/branson-school-of-entrepreneurship. [Accessed 09 November 2011].

Von Broembsen, M., Wood, E., Herrington, M., Shay, D. \& Sheppers, R. (2005). Global entrepreneurship monitor, South African Report, UCT, Cape Town.

Young Upstarts Report. (2011). Instant Grass for Virgin Unite [online]. Available at: http://www.instantgrass.com/wp-content/uploads/2011/06/YUR.pdf. [Accessed 07 April 2011].

Youth Business International. (2009). Youth entrepreneurship. Recommendations for action

[Online]. Available

at: http://www.pdp.com.sv/main/archivos/publicaciones/RecommendationsforAction.pdf. [Accessed 02 December 2011].

Youth Development Network. (2004). South Africa Addressing Youth Unemployment-the Most Pressing Post-Apartheid Development Challenge for youth [online]. Available at: http://www.unhabitat.org/downloads/docs/268South_Africa_AddressYDNPaperforEGM.pdf. [Accessed 02 December 2011]. 